\title{
THREATS TO HEALTH AND SAFETY AT WORK WHEN COMPLETING A WAREHOUSE PROCESS
}

\section{MARIUSZ SOWA}

University of Szczecin, POLAND

e-mail: mariusz.sowa@wzieu.pl

RECEIVED
ACCEPTED
JEL
CLASSIFICATION

KEYWORDS

ABSTRACT

\author{
20 April 2018 \\ 12 July 2018 \\ D02, D29, D81
}

warehouse process, work safety, sources of work safety hazards

Artykuł ma za zadanie wskazać rodzaje i źródła zagrożeń bezpieczeństwa pracy przy realizacji procesu magazynowego. Przedstawione opracowanie koncentrować się będzie na wybranych grupach zagrożeń, jakie stanowić mogą m.in. wyposażenie technologiczne magazynu, w tym urządzenia do składowania i magazynowe środki transportowe czy zagrożenie pożarowe. Oprócz technicznych zagrożeń bezpieczeństwa, wskazano także na aspekt organizacyjny, który ma także istotny wpływ na bezpieczeństwo pracy w magazynie.

Article aims to identify the types and sources of threats to safety during of the warehouse process. This paper will focus on the on selected sections of the risks that may constitute, among others, technological equipment of the warehouse, including storage devices and means of warehouse transport or fire risk. In addition to technical security threats, the article also presents an organizational aspect that also has a significant impact on work safety in the warehouse.

\section{Introduction}

Identification of threats in warehouse processes is crucial to prepare appriopriate procedures and plans to ensure healths and safety at work. One of the method applied as basic research techniques in social sciences is observation. In the context of preapred article the observation was applied to identify the phenomena, behaviors, events that couses risks in the warehouse processes. 
A warehouse process is a set of warehouse operations put in a chronological order, completed in places which are appropriately adapted to it and in particular subject to organizational and technological conditions. This process is divided into four basic phases: receiving, storing, completing and shipping (Niemczyk, 2010, p. 10).Warehouse activities, which consist in lifting, moving, repacking, weighing, completing or stacking up are performed by warehouse people who can have either direct (when the activities are performed manually) or indirect (when the abovementioned activities are performed mechanically) contact with the load. All operations which make up the warehouse process are done with the use of stock, machines and storage facilities thanks to which they are moved and stored, stockroom and staff. However, when it comes to protection against hazards, the most important element of this process is warehouse staff who is responsible for managing and completion of warehouse operations in accordance with the specified procedures (Dudziński, Kizyn, 2002, p. 507). For the warehouse process to be completed efficiently and safely, all elements that constitute it should meet specified requirements which have been presented in Table 1.

Table 1. The elements of the warehouse process and conditions they need to met in order to ensure a safe completion of the process

\begin{tabular}{|c|c|}
\hline Elements of the warehouse process & Security requirements \\
\hline Stock & $\begin{array}{l}\text { - suitably packed, } \\
\text { - suitably labelled, } \\
\text { - secured for transport, } \\
\text { - secured for storage, } \\
\text { - ensuring appropriate storing conditions }\end{array}$ \\
\hline Machines and storage facilities & $\begin{array}{l}\text { - adapted to performer activities, } \\
\text { - adapted to stock they are used to deal with, } \\
\text { - holding a certificate, regularly reviewed, } \\
\text { - in a working order, } \\
\text { - having information on permissible load of floor, ceiling and storage facilities, } \\
\text { - of adequate strength and stable construction, } \\
\text { - storage facilities which have protection against falling, } \\
\text { - the clearance between racks for means of transport (fork lift maneuvering area) }\end{array}$ \\
\hline Stockroom & $\begin{array}{l}\text { - of adequate shape, } \\
\text { - suitable construction, } \\
\text { - suitable strength and technical condition, } \\
\text { - right measurements (e.g. in a warehouse with the right parameters each worker should be provided with } \\
13 \mathrm{~m}^{2} \text { of free space and at least } 2 \mathrm{~m}^{2} \text { of floor which is not crammed with any machines or facilities), } \\
\text { - non-slip and dust-free floor, } \\
\text { - outlined landfill sites, } \\
\text { - designated cubic volume, } \\
\text { - designated manoevuring lanes, } \\
\text { - designated transport corridors, } \\
\text { - marking rooms with evacuation signs, } \\
\text { - adequately equipped (e.g. a room for battery storage should be an adequately adapted and equipped } \\
\text { accumulator plant whose walls and floor ought to be lined with acid-proof material, have gravity ventilation } \\
\text { in the ceiling and safe explosion protected lighting. The door of such a room should open outwards) }\end{array}$ \\
\hline Warehouse staff & $\begin{array}{l}\text { - have knowledge and skills essential to perform warehouse activities, } \\
\text { - have qualifications to operate machines and devices, } \\
\text { - equipped with adequate personal protective equipment, } \\
\text { - the state of physical and mental health enables them to perform activities in a safe way, } \\
\text { - take care of an adequate working order of machines, devices and tools, } \\
\text { - make sure that their workplace is tidy, } \\
\text { - adhere to health and safety at work regulations, } \\
\text { - adhere to orders and decisions included in the warehouse instruction, } \\
\text { - participate in health and safety at work training and first aid courses }\end{array}$ \\
\hline
\end{tabular}

Source: own work based on: Dudziński, Kizyn (2002), pp. 507-508; Dudziński (2003), pp. 208-212. 
Failure to meet any legal and regulatory requirement of the warehouse process results in a health and life hazard for staff, surrounding, as well as the risk of the load, facilities or stockroom being damaged or destroyed (Dudziński, Kizyn, 2002, p. 508).

\section{Storage facilities and lift trucks hazards}

Storage facilities and lift trucks hazards Shelving units are the most common among storage facilities. These are facilities whose construction solutions allow to pile supplies directly on elements or by means of additional devices (Niemczyk, 2010, p. 82). One faces the issue of security at the time of these units are selected (decision about a manufacturer - consulting, project, shipment, assembly), but also when they are used (periodical evaluation of technical condition, maintenance, operational culture).

Warehouse shelving units enable to use warehouse storage area more efficiently, increase the safety of workers, and facilitate the operations of the warehouse process, but only when requirements specified in the following regulations are met:

- the Act of the Minister of Labour and Social Polity of 26 September 1997 on health and safety at work regulations (Journal of Regulations No. 129, heading 844),

- PN-88/M-78321 - Freestanding shelving units - requirements and research,

- PN-91/M-78323 - Gravitational shelving units - requirements and research,

- PN-88/M-78325- Warehouse storage facilities. Vertical sheet racks.

Storage facilities pose occupational risk when:

- unit loads which are stored on them are not of the right size, shape or weight (e.g. the weight of the load cannot exceed the permissible loads of a shelving unit),

- they do not have a stable and durable construction and elements which prevent it from turning over (the construction does not ensure stability of position),

- they are not equipped with elements protecting unit loads which are exposed to mechanical damage caused by the means of transport,

- are used in rooms polluted by steam or gases of corrosive substances that affect the construction of the storage facility and weaken connectors and bearing elements,

- the clearance between storage facilities does not enable to move safely and to operate the means of transport,

- hazardous and chemical substances are stored at top shelves of shelving units,

- additional elements which protect unit load against turning over or falling down the shelving unit (with account being taken in particular to objects whose shape and weight decide about individual way of storage) (Dudziński, Kizyn, 2008, pp. 343-344).

In order to increase safety during the completion of operations in the warehouse process by means of shelving units, it is recommended to chose a professional manufacturer of shelving units who provides comprehensive service, from consulting service, design, delivery to fitting and training warehouse staff in usage and safe operation. It is also important to reinforce the construction of shelving units, which is especially important in warehouse where the traffic of forklift trucks is increased and/or culture of driving a forklift truck is low. There is also a possibility to increase the safety of shelving units by means of purchasing additional equipment, such as dock bumper installed 
on the shelving's pole, dock bumpers installed on the shelving's frame or pallet stops. Unfortunately, these solutions are rarely used in practice because of bearing additional costs of their purchase.

Infrastructure of internal transport consists of moving work equipment and additional equipment which enable to transfer products in storage processes efficiently and effectively, starting from unloading of external transport, moving inside the warehouse, to stacking in the storing process, order compilation and unloading (Wojciechowski, Kosmatka, 2009, p. 113; Dudziński, 2003, p. 85). The devices which pose the highest risk to occupational safety include warehouse means of transport such as forklift trucks, overhead cranes, stacker cranes, conveyors and lifts (Dudziński, Kizyn, 2002, p. 510). They constitute an inherent element of almost every warehouse. They are used to move cargo in the warehouse as well as in reloading and storing processes. They are essential in the completion of numerous tasks. In order to ensure occupational safety when transport facilities are used, it is necessary to adhere to norms which apply to the parameters of transit routes whey use. An example includes the required width of a transit routes, specified in the Polish Norm, which has been presented in Table 2.

Table 2. Minimum width of transit routes

\begin{tabular}{|c|c|c|c|c|}
\hline \multirow{2}{*}{$\begin{array}{l}\text { Item } \\
\text { number }\end{array}$} & & \multirow[b]{2}{*}{ Designation of a route } & \multicolumn{2}{|c|}{ Minimum $(\mathrm{cm})$} \\
\hline & & & $\begin{array}{c}\text { non-motorized means } \\
\text { of transport }\end{array}$ & $\begin{array}{c}\text { motorized means } \\
\text { of transport }\end{array}$ \\
\hline \multirow{2}{*}{1.} & \multirow{2}{*}{ Unidirectional traffic } & Only for means of transport & $B=a+60$ & $B=a+60$ \\
\hline & & For means of transport and pedestrian traffic & $B=a+90$ & $B=a+100$ \\
\hline \multirow{2}{*}{2.} & \multirow{2}{*}{ Bidirectional traffic } & Only for means of transport & $B=2 a+90$ & $B=2 a+90$ \\
\hline & & For means of transport and pedestrian traffic & $B=2 a+180$ & $B=2 a+200$ \\
\hline
\end{tabular}

Where: $a$ is the width of the means of transport; $b$ is the width of the transit route.

Source: Skuza, Wojciechowska-Piotrowska (2001), p. 25.

Safe technological transport facilities are facilities which have an actual CE mark which confirms that they comply with EU standards. According to EU law, only a manufacturer or authorized marketers have the right to grant CE marks. Nevertheless, it needs to be remembered that occupational safety and reliability of means of transport is directly linked to skills and experience of people who operate them. Hence the directive of the Minister of Economic Affairs of 10 May 2002 on industrial safety when using motorized lift trucks (Journal of Regulations no. 70, heading 650 with further amendments), which specifies the requirements to be met by a lift truck operator. Completing a lift truck operator course is not enough to ensure efficient and safe work. Special attention needs to be also paid to maintenance of fork trucks, such as cleaning them or checking their working order before starting to use them. Unfortunately, employers often ignore this duty and do not enforce fulfillment of these duties by their employees. Not only does this increase the risk of accidents, but also the operating costs and subsequent maintenance service costs. Lift truck manufacturers offer devices which have an increasingly better technical performance and which have numerous functions of both the proplusion system and chassis (Trochymiak, 2018, http://www.pracujwlogistyce. pl/20-poradnik-eksperta/222-podczas-wakacji-zadbaj-o-bezpieczne-miejsca-pracy-w-magazynie?tmpl=compone nt\&print=1\&page=). Working on such a technologically advanced device forces its operator to have a specialist training thanks to which potential problems with its operation are avoided. However, before an electric fork lift truck is authorized for use in a warehouse, it needs to be reported to the Office of Technical Inspection. There is not any such obligation in case of live skids which does not mean that they can be defective or that it is possible for them not 
to have name templates, safe working load templates or operation and maintenance documentation (Malczewski, 2010, http://www.utrzymanieruchu.pl/menu-gorne/artykul/article/bezpieczny-magazyn-to-czysty-zysk/part/3). As in the case of storing facilities, it is the duty of the employer to maintain lift trucks in good order and to have them periodically reviewed. Factors which influence occupational safety when forklift trucks are used include:

- appropriately prepared forklift truck operator training courses,

- having a forklift truck license,

- an operator's good visibility of the surroundings,

- an operator of the forklift truck has to maintain the appropriate center of gravity of their load,

- batteries of forklift trucks have to be charged in designated points and by designated workers,

- using personal protective equipment,

- not working under time pressure and concentrating when completing one's tasks,

- monitoring the implementation of work rules.

The most common cause of accidents in a warehouse involving forklift trucks is inappropriate organization of work and human error (excessive speed, overload, transporting third parties). They often lead to loss of health or life, damage to property, high repair expenses or interruption to the continuity of work.

\section{Warehousing fire hazards}

The term fire hazard refers to the a group of factors and circumstances which create conditions for the occurrence and spread of fire, as well as the development of toxic gases and smoke which pose risk to human life. On the basis of fire hazard, materials can be divided into two main groups: flammable and non-flammable. The first group includes:

- highly flammable materials are substances that initiate fire (self-ignition) - straw, flax and substances which when come into contact with the source of heat catch fire and keep burning without the need of secondary initiation,

- flame-retardant substances - they are substances which burn only when there is stable source of ignition or heat and die down as a result of its lack.

Non-flammable substances are substances which do not burn when subjected to fire or temperature (Niemczyk, 2012, p. 215).

There are three factors that have to occur at the same time to start and maintain fire: heat (energy), oxygen and fuel. The size of fire is mainly dependent on the availability of oxygen and fuel. Lack of any of the abovementioned elements causes the fire to die down (Bogdan, Chudzińska, 2008, p. 2). The most common causes of fire in a warehouse include above all:

- defects and default mode of installation and electric appliances (incorrect workmanship, overloads caused by connecting a lot of loading points to a single electrical circuit),

- using open fire and smoking cigarettes in places where it is forbidden, storing flammable materials in conditions in which critical temperature is exceeded,

- electrical circuit overload, crushed electric insulation, damage to electric insulation or loose electric connection,

- using inadequate transport equipment,

- inadequate storage or usage of flammable materials, 
- workers' insufficient knowledge of hazards related to storage facilities, warehouse transport equipment and measuring and control equipment.

In general supplies stored in warehouses are of flammable character (such as due to their card packaging). The kind of (flammable) materials stored in a warehouse and its number stored in a warehouse constitute the socalled fire load. Fire load $Q_{d}$ is heat that is released when flammable materials found in the warehouse fire zone are burnt and which is equivalent to burnt wood in $\mathrm{kg}$ with net caloric value of $4,400 \mathrm{kcal} / \mathrm{kg}(18.4 \mathrm{MJ} / \mathrm{kg})$ per $1 \mathrm{~m}^{2}$ of warehouse plan level (PN-70/B-02852, Marysiuk, 2011).

Fire load $Q_{d}$ can be determined by the following relation (Dudziński, Kizyn, 2002, p. 529):

$$
Q_{d}=Q_{c} \times \frac{G}{F}\left(M J / m^{2}\right),
$$

where:

$Q_{c}$ - is the caloric value of the material $(\mathrm{MJ} / \mathrm{kg})$,

$G$ - a mass of the material $(\mathrm{kg})$,

$F$ - the surface of warehouse plan level $\left(\mathrm{m}^{2}\right)$.

The fire resistance class of a building is determined on the basis of the calculated value of fire load $Q_{d}$, which has been presented in Table 3. Five classes of fire resistance, designated by the following letters: A, B, C, D and E, ordered from the highest to the lowest resistance, have been determined.

Tahle 3. Warehouse fire resistance classes

\begin{tabular}{cl}
\hline Fire resistance class & \multicolumn{1}{c}{ Maximum fire load density $Q_{d}$ of a fire zone in a building $\left(M J / \mathrm{m}^{2}\right)$} \\
\hline A & buildings with a fire zone having fire load $Q_{d}>4,000$ \\
\hline$B$ & $\begin{array}{l}\text { buildings with a fire zone having fire load } Q_{d}>, 2000 \text { do } Q_{d}=4,000, \\
\text { high buildings with a fire zone having fire load } Q_{d} \leq 2,000\end{array}$ \\
\hline$C$ & $\begin{array}{l}\text { buildings with a fire zone having fire load } Q_{d}>1,000 \text { do } Q_{d}=2,000, \\
\text { medium-height buildings with a fire zone having fire load } Q_{d} \leq 1,000\end{array}$ \\
\hline$D$ & $\begin{array}{l}\text { buildings with a fire zone having fire load } Q_{d}>500 \text { do } Q_{d}=1,000, \\
\text { multi-storey low buildings with fire zones having fire load } Q_{d} \leq 500\end{array}$ \\
\hline$E$ & single storey buildings with a fire zone having fire load $Q_{d} \leq 500$ \\
\hline
\end{tabular}

Source: Rączkowski (2010), p. 111; Dudziński, Kizyn (2002), p. 530.

The fire resistance of a building results from the fire resistance of its constructional elements as well as materials they are made of. Each building that functions as a warehouse should be designed in a way that its elements retain its mechanical strength, fire integrity and thermoinsulating power.

\section{Conclusions}

The process by means of which health and safety standards are risen should become an element of the strategy of an organizational and functional unit allotted to store tangible material goods temporary excluded from logistic channel (supplies). There are several factors that influence safety in a warehouse: from the construction of the warehouse, the kind and number of stored supplies, the selection and usage of technological and installation 
and construction equipment to employing qualified warehouse staff who adhere to legal regulations. In order to increase safety during the completion of operations in the warehouse process, it is essential to ensure not only the adequate level of employees' professional qualifications, match facilities to the specificity of a warehouse and the kind of performed activities, but also control adherence to work rules. One of the most important factors contributing to improvements in the safety and health in a warehouse is undoubtedly the right organization of work which ensures not only efficiency of the storage process, but above all a safe workplace.

\section{References}

Bogdan, A., Chudzińska, M. (2008). Wybrane aspekty ochrony przeciwpożarowej w budynkach. Bezpieczeństwo Pracy - Nauka i Praktyka, 2 (2).

Dudziński, Z.(2003). Jak sporządzić instrukcję magazynową. Gdańsk: ODiDK.

Dudziński, Z., Kizyn, M. (2008). Poradnik magazyniera. Warszawa: PWE.

Dudziński, Z., Kizyn, M. (2002). Vademecum gospodarki magazynowej. Gdańsk: ODiDK.

Marysiuk, S. (2011). Zabezpieczenie przeciwpożarowe budowli magazynowych. Transport Wewnętrzny i Magazynowanie, 2.

Niemczyk, A. (2012). Zarządzanie magazynem. Poznań: WSL.

PN-70/B-02852 Ochrona przeciwpożarowa w budownictwie. Obliczanie obciążenia ogniowego oraz względnego czasu trwania pożaru.

Rączkowski, B. (2010). BHP w praktyce. Gdańsk: ODiDK.

Skuza, L., Wojciechowska-Piotrowska, H. (2001). BHP przy magazynowaniu. Gdańsk: ODiDK.

Wojciechowski, Ł., Wojciechowski, A., Kosmatka, T. (2009). Infrastruktura magazynowa i transportowa. Poznań: WSL.

Cite this article aS: Sowa, M. (2018). Threats to health and safety at work when completing a warehouse process. European Journal of Service Management, 3 (27/1), 285-291. DOI: 10.18276/ejsm.2018.27/1-36. 